Article 30 - Protection in the event of unjustified dismissal

\title{
Jeff Kenner*
}

Every worker has the right to protection against unjustified dismissal, in accordance with Union law and national laws and practices.

\section{Explanation on Article 30}

This Article draws on Article 24 of the revised Social Charter. See also Directive 2001/23/EC on the safeguarding of employees' rights in the event of transfers of undertakings, and Directive 80/987/EEC on the protection of employees in the event of the insolvency of their employer, as amended by Directive 2002/74/EC.

\section{Select bibliography}

Anderman S, 'Termination of Employment: Whose Property Rights?' in C Barnard, S Deakin and G S Morris (eds), The Future of Labour Law (Oxford, Hart, 2004) 101-128 Barnard C, EU Employment Law, Fourth ed (Oxford, Oxford University Press, 2012) Collins H, Justice in Dismissal (Oxford, Clarendon Press, 1992).

Hepple B, 'European Rules on Dismissals Law?' (1997) Comp Labour Law J 204 at 21012

Hepple B, 'A Right to Work?' (1981) 10 ILJ 65

Kenner J, 'New Frontiers in EU Labour Law: From Flexicurity to Flex-Security' in M Dougan \& S Currie (eds), 50 Years of the European Treaties: Looking Forward and Thinking Back (Oxford, Hart, 2009) 279-310

Miller K, 'The American Employment-at-Will Doctrine and its Impact upon Employee Rights' (2001) 5 Edinburgh L Rev 169

Napier B, 'Dismissal - The New ILO Standards' (1983) 12 Industrial Law Journal 17 Wedderburn (Lord), 'The Italian Workers Statute: British Reflections on a High Point of Legal Protection’ (1990) 19 ILJ 154

\section{Table of Contents}

A. Article 30 and the Scope of EU Law

B. Interrelationship of Article 30 with other provisions of the Charter

C. Sources of Article 30 Rights

D. Analysis

E. Evaluation

A. Article 30 and the Scope of EU Law

Article 153(1)(d) TFEU provides a specific legal basis for the adoption of directives in the field of 'protection of workers where their employment contract is terminated'. ${ }^{1}$ This provision originated in the Social Policy Agreement annexed to the Treaty of Maastricht, 1993, and was later incorporated into the EC Treaty by the Treaty of Amsterdam, 1999,

*Professor of European Law, University of Nottingham: jeffrey.kenner@ nottingham.ac.uk

${ }^{1}$ When read in conjunction with Art 153(2)(b) TFEU. 
but it remains dormant twenty years on. As a result, Article 30 lacks the bite that would otherwise be provided by a comprehensive normative framework in EU law to protect 'every worker' against 'unjustified dismissal'. However, there are many interactions with EU legislation, Charter provisions and international norms that, in combination, have the potential to bring Article 30 within the scope of EU law in certain situations.

There are several reasons for the EU's failure to adopt a specific directive on unjust dismissal, which, taken together, shine a light on some of the difficulties in converting Article 30 into a fully-fledged job security right for all workers within the scope of EU law. Firstly, there is a requirement of unanimity in the Council for the adoption of specific directives to protect workers on the termination of their employment contract. Even after the entry into force of the Treaty of Lisbon, 2009, the Member States have shown little desire to support legislation at EU level. Regulation of termination of employment is one of only three fields of social policy listed in Article 153(1) TFEU to fall outside the ordinary legislative procedure. ${ }^{2}$ Secondly, the Community Charter of the Fundamental Social Rights of Workers (EU Social Charter), ${ }^{3}$ which provided the primary stimulus for legislative social activism in the 1990s, contains no express reference to the general protection of workers in the event of termination of employment. Thirdly, and by way of explanation for the above omission, such a right is also absent from the European Social Charter (ESC), 1961. ${ }^{4}$ This gap in protection was not rectified until the Revised European Social Charter (RESC), 1996, ${ }^{5}$ but, as of 26 March 2013, only 18 of the EU-28 had ratified the RESC. ${ }^{6}$ Moreover, ILO Convention No 158 on Termination of Employment, 1982, which was the primary source for Article 24 RESC, has attracted just ten ratifications from among the EU Member States. ${ }^{7}$ Fourthly, the Commission has lacked the political will to bring forward a legislative proposal on termination of employment because it has found it difficult to provide a compelling rationale, on its own terms, for a proposal rooted in job security over a period when the driving dynamic of EU social policy has favoured 'labour market flexibility' and 'light touch' regulation. By 2006, the Commission was postulating the notion that the 'traditional model' of labour law based on protection for the 'standard' contractual employee in a particular job was outdated. ${ }^{8}$ Instead, the Commission favours more inclusive, but diluted, protection for all workers in an increasingly diverse and fragmented labour market and managing employment transitions from one status to another.

\footnotetext{
${ }^{2}$ The other fields in this group are: social security and social protection of workers; representation and collective defence of the interests of workers and employers, including co-determination; and conditions of employment for third-country nationals legally residing in Union territory.

${ }^{3}$ The Social Charter was adopted on 9 Dec 1989 by 11 of the then 12 Member States as a solemn declaration: http://www.aedh.eu/The-Community-Charter-of.html

${ }^{4}$ Council of Europe, European Treaty Series No 35, 18 Oct 1961: http://conventions.coe.int/Treaty/EN/Treaties/Html/035.htm

${ }^{5}$ Council of Europe, European Treaty Series No 163, 3 May 1996: http://www.conventions.coe.int/Treaty/EN/Treaties/Html/163.htm

${ }_{7}^{6}$ See: http://www.coe.int/t/dghl/monitoring/socialcharter/Presentation/Overview_en.asp

${ }^{7}$ Available at: http://www.ilo.org/dyn/normlex/en/

${ }^{8}$ Commission Green Paper, Modernising labour law to meet the challenges of the $21^{\text {st }}$ century, COM (2006) 708 final, 22 Nov 2006. See J Kenner, 'New Frontiers in EU Labour Law: From Flexicurity to FlexSecurity' in M Dougan \& S Currie (eds), 50 Years of the European Treaties: Looking Forward and Thinking Back (Oxford, Hart, 2009) 279-310.
} 
The Commission's inertia can, in part, be explained by the general ambiguity of the right itself. The right to protection against unjust dismissal is an essentially defensive right to protect the worker against the abuse of managerial power. ${ }^{9}$ It can apply in the context of termination of employment connected with the capacity or conduct of the worker or an economic dismissal. ${ }^{10}$ Legislation on job security may deter or prevent the employer from simply firing at will, as is the norm in the United States, ${ }^{11}$ and, in some Member States, there is the possibility of reinstatement in the job.

It is also important to note that the scope of Article 30 is limited somewhat by the caveat that the operation of the right to protection against unjustified dismissal is in accordance with both Union law and 'national laws and practices'. According to Article 52(6) of the Charter: 'Full account shall be taken of national laws and practices as specified in the Charter', which means, by reference to the explanation on Article 52, that the 'spirit of subsidiarity' applies. The extent to which this restricts the scope of Article 30 is doubtful but, at the very least, it ensures that where the national law and practice falls outside the scope of application of the Charter, as defined in Article 51, or action by Member States is merely optional under EU law, or indeed international law, Article 30 will not be directly engaged.

Moreover, Article 2 of Protocol 30 on the application of the Charter to Poland and the United Kingdom, annexed to the EU treaties, may also come into play as it provides that where 'national laws and practices' are referred to in a provision of the Charter the right in question shall only apply in the two named Member States 'to the extent that the rights or principles that it contains are recognised in the law or practices of Poland and the United Kingdom'. This reinforces Article 1(2) of the Protocol which declares that 'nothing' in Title IV of the Charter, which includes Article 30, 'creates justiciable rights' applicable to Poland or the United Kingdom 'except in so far as Poland or the United Kingdom has provided for such rights in its national law'. The limited scope of Article 30 suggests that the impact of the Protocol is not significant but it does act as a potential brake on the development of EU law in this area. It is important to note, however, that the Protocol is not an opt-out and it does not exempt Poland or the United Kingdom from the obligation to comply with the provisions of the Charter or to prevent a court of one of those Member States from ensuring compliance with those provisions. ${ }^{12}$

EU law does, however, offer a degree of protection to individual workers in the event of termination of their contract or employment relationship in several specific contexts. There is, therefore, the potential for Article 30 be activated and for its sources in international law to be a point of reference for judicial interpretation within the scope of EU law.

The Transfers of Undertakings Directive, 2001/23, ${ }^{13}$ first adopted in 1977, is referenced in the explanations on Article 30. It is intended to safeguard the acquired

\footnotetext{
${ }^{9}$ See H Collins, Justice in Dismissal (Oxford, Clarendon Press, 1992) 1-5.

${ }^{10}$ Art 4, ILO Convention No 158.

${ }^{11}$ See K Miller, 'The American Employment-at-Will Doctrine and its Impact upon Employee Rights' (2001) 5 Edinburgh L Rev 169.

${ }^{12}$ Cases C-411/10 N.S. v Secretary of State for the Home Department and C-493/10 M.E. and Others v Refugee Applications Commissioner, Minster for Justice, Equality and Law Reform, 21 Dec 2011

${ }^{13}$ Council Directive 2001/23/EC of 12 March 2001 on the approximation of the law of the Member States relating to the safeguarding of employees' rights in the event of transfers of undertakings, businesses or
} 
employment rights of contracted employees in the event of a business restructuring involving a change of employer. It offers protection only in the context of the termination of an employment relationship by reason of the transfer of an undertaking, business, or part thereof to another employer as a result of a legal transfer or merger. ${ }^{14}$ Article $4(1)$ provides that the transfer shall not 'in itself' constitute grounds for dismissal by the transferor or the transferee. It does, however, allow for dismissals that may take place for 'economic, technical or organisational reasons entailing changes in the workforce'. It therefore balances protection for the employees with the commercial considerations of the transferor and the transferee. Article 4(2) is more explicit on the justice of the dismissal. It provides that if the employment contract is terminated because the transfer involves a 'substantial change' in working conditions to the 'detriment' of the employee, the employer 'shall be regarded as having been responsible' for the termination.

Reference is also made in the explanations on Article 30 to the Insolvency Directive, 2008/94/EC, ${ }^{15}$ first introduced in 1980. The Directive is primarily concerned with ensuring a 'minimum degree' of protection for employees in the event of the insolvency of their employer. ${ }^{16}$ Member States are required to establish a body which guarantees payment of the outstanding contractual claims of employees. Under Article 3, these payments are to include, where provided for by national law, 'severance pay' on termination of employment relationships. The purpose is to provide a modicum of compensation by society for the unfairness suffered by employees in economic circumstances for which they cannot be held to be responsible. Fundamental rights are not at the forefront and it is noticeable that neither the Directive, as amended, nor the Charter, contains a reference to Article 25 RESC which recognises a 'right of workers to the protection of their claims in the event of the insolvency of their employer'.

Unlike in the case of the Transfers of Undertaking Directive, there is no new employer to take over the ownership of the business in an insolvency scenario, but Article 8 recognises acquired rights, or a property dimension to the job, by placing an obligation on Member States to take the 'necessary measures' to protect both employees and persons who have already left the undertaking or business at the date of the onset of the employer's insolvency in respect of rights conferring on them immediate or prospective entitlement to old-age benefits, including survivors' benefits, under occupational pensions schemes.

In both of the above examples, Article 30 has the potential to buttress the established rights of employees on termination of employment under EU law. It can be argued that Article 30 is somewhat incidental to the main purposes of these directives, which are essentially concerned with managing the processes of corporate restructuring and insolvency. This may explain why the Court of Justice has not, to date, cited Article 30 in its judgments in cases referred by the national courts on the scope of the employment protection provisions in either of the two directives. The Court of Justice

parts of undertakings or businesses, OJ L 82, 22.3.2001, p 16. The Directive repealed and replaced Directive 77/187/EEC and its amendment, Directive 98/50/EC.

${ }^{14}$ Ibid, Art 1(a).

${ }^{15}$ Directive 2008/94/EC of the European Parliament and of the Council of 22 Oct 2008 on the protection of employees in the event of the insolvency of their employer (codified version), OJ L 283, 28.10.2008, p 36. The Directive repealed and replaced Directive 80/987/EEC and its amendments, Directives 87/164/EEC and 2002/74/EC.

${ }^{16}$ Ibid, recital 3 of the preamble. 
has, however, made reference to Article 16 of the Charter laying down the freedom to conduct a business when exercising the managerial prerogative in the context of a transfer of an undertaking. ${ }^{17}$

The explanations make no reference to the Collective Redundancies Directive, $98 / 59,{ }^{18}$ despite the fact that, alone among EU social policy directives, it is concerned exclusively with the process of termination of the employment relationship. Directive 98/59 applies in situations where an employer decides to cease to run a business at a particular location or to reduce the number of employees employed there. ${ }^{19}$ In part, this omission can be explained by the essentially procedural objectives of the Directive, which is not directly concerned with the substantive employment rights of those workers who might potentially be affected when an employer contemplates making collective redundancies. The main purpose of the Directive is to provide a loose framework within which the parties, including representatives of the employer and the workers, can conduct the practical arrangements and procedures for such 'collective redundancies'. As such, it fits more closely with Article 27 of the Charter on the right of workers to 'information and consultation within the undertaking'. Nevertheless, Article 30 is relevant because effective involvement of workers' representatives is of vital importance for individuals facing dismissal as a consequence of economic re-organisation.

Specific prohibition of dismissal from employment can be found in EU legislation concerning family life. Article 10 of the Pregnancy and Maternity Directive, 1992/85, ${ }^{20}$ prohibits the dismissal of pregnant workers and workers who have recently given birth or are breastfeeding. Dismissal of these workers is deemed automatically unjustified without the need to look at motive or to use EU gender equality law to establish unequal treatment. The legislator's rationale is the need to guarantee the right of workers falling within the scope of the Directive to health and safety protection.

Clause 2(4) of the revised Framework Agreement annexed to the Parental Leave Directive, 2010/18, ${ }^{21}$ requires Member States to take the 'necessary measures' to protect workers against dismissal on the grounds of an application for, or taking of, parental leave in accordance with national law, collective agreements or practices. In a similar vein, Article 16 of the recast Directive on Equal Treatment of Men and Women, $2006 / 54,{ }^{22}$ provides for protection against dismissal for workers exercising rights to

\footnotetext{
${ }^{17}$ Case C-426/11 Alemo-Herron v Parkwood Leisure Ltd, 18 July 2013, discussed in part DI.

${ }^{18}$ Council Directive 98/59/EC of 20 July 1998 on the approximation of laws of the Member States relating to collective redundancies, OJ L 225, 12.8.1998, p 16 (as corrected by Corrigendum, OJ L 59, 27.2.2007). Directive 98/59 repealed and replaced Directive 75/129/EEC and its amendment, Directive 92/56/EEC.

19 At least ten workers in establishments normally employing more than 20 and less than 100 workers; at least $10 \%$ of workers in establishments normally employing between 100 and 299 workers; or at least 30 workers in establishments normally employing 300 workers or more - Art 1(a)(ii), ibid.

${ }^{20}$ Council Directive 92/85/EEC on the introduction of measures to encourage improvements in the safety and health at work of pregnant workers and workers who have recently given birth or are breastfeeding (tenth individual Directive within the meaning of Article 16 (1) of Directive 89/391/EEC), OJ L 348, 28.11.1992, p 1 .

${ }^{21}$ Council Directive 2010/18/EU of 8 March 2010 implementing the revised Framework Agreement on parental leave concluded by BUSINESSEUROPE, UEAPME, CEEP and ETUC and repealing Directive 96/34/EC, OJ L 68, 18.3.2010, p 13.

${ }^{22}$ Council Directive 2006/54/EC of 5 July 2006 on the implementation of the principle of equal opportunities and equal treatment of men and women in matters of employment and occupation (recast), OJ L 204, 26.07.2006, p 23.
} 
paternity and/or adoption leave but only where such rights are recognised by Member States.

Each of these family life related dismissal scenarios is captured by Article 33(2) of the Charter. It is important to note, however, the link between the specific protections provided in these directives and the importance, in the wider sense, of upholding the principles of dignity and autonomy of the individual that are central to the conception of fairness in dismissal. ${ }^{23}$

Finally, Article 30 is relevant in protection against dismissal in the context of combating discrimination on one or more of the grounds referred to in Article 19 TFEU $^{24}$ and providing for equal treatment between men and women in employment and occupation under Article 157 TFEU. Article 14(1)(c) of the recast Directive on Equal Treatment of Men and Women, 2006/54, ${ }^{25}$ prohibits direct or indirect discrimination in relation to employment and working conditions 'including dismissals'. Equivalent provisions can be found in Article 3(1)(c) of Directive 2000/43 ${ }^{26}$ on race discrimination and Article 3(1)(c) of the general non-discrimination Directive, 2000/78. ${ }^{27}$ Moreover, dismissal for reasons connected with discrimination is not valid under the norms of the ILO and the Council of Europe on protection in the event of termination of employment initiated by the employer. ${ }^{28}$

On the one hand, Article 30 appears somewhat nugatory in the non-discrimination and equal treatment context as it is superseded by more direct application of Articles 21 and 23 of the Charter. However, on the other hand, it may have particular relevance in the context of age discrimination where, by contrast with the other grounds of discrimination, directly discriminatory dismissal rules, such as a fixed retirement age, are capable of justification by an employer who can show that the provisions in question are 'objectively and reasonably justified by a legitimate aim' and proportionate. ${ }^{29}$

\section{B. Interrelationship of Article 30 with other provisions of the Charter}

In order to identify the relationship of Article 30 with other Charter provisions, it is necessary to conceptualise justice in the context of dismissal by an employer. Hugh Collins has identified two rationales for laws against unjust or unfair dismissal. ${ }^{30}$ Firstly, by providing for fairness in the process and substance of dismissal, such laws respect the dignity of the individual worker and, secondly, they foster autonomy by improving a worker's job security. The granting of the right endows the worker with an interest in job security but not necessarily an ownership or property right in the job.

Collins' dignity rationale is immediately relevant when Article 1 is considered. Article 1 declares that human dignity is 'inviolable' and 'must be respected and

\footnotetext{
${ }^{23}$ See Collins, above n9, 9-23.

${ }^{24} \mathrm{Sex}$, racial or ethnic origin, religion or belief, disability, age or sexual orientation.

${ }^{25}$ See above $\mathrm{n} 22$.

${ }^{26}$ Council Directive 2000/43/EC of 29 June 2000 implementing the principle of equal treatment between persons irrespective of racial or ethnic origin, OJ L 180, 19.7.2000, p 22.

${ }^{27}$ Council Directive 2000/78/EC of 27 November 2000 establishing a general framework for equal

treatment in employment and occupation, OJ L 303, 2.12.2000, p 16.

${ }^{28}$ See part C.

${ }^{29}$ Ibid, Art 6, discussed in part DIII.

${ }^{30}$ See Collins, above n9, 21.
} 
protected'. Human dignity is an inherent right for all human beings derived from the Universal Declaration of Human Rights. The explanations state that 'none of the rights' in the Charter 'may be used to harm the dignity of another person, and that the dignity of the human person is part of the substance of the rights laid down in this Charter'. As Article 30 is expressed positively as a right and may conflict with other rights and freedoms in the Charter, such as Article 16 on the freedom to conduct a business, this wording is important. At the very least, Article 30, read together with Article 1, recognises that, even if the decision to dismiss a worker is a legitimate exercise of the managerial prerogative, it is necessary for the employer to act rationally by respecting and protecting the worker's right to be treated with dignity in the conduct of that dismissal. $^{31}$

Article 3 brings into play the autonomy rationale suggested by Collins. It states that 'everyone has a right to respect for his or her physical and mental integrity'. Success at work, or the ambition to succeed and be satisfied in the work environment, is integral to personal autonomy and physical and mental well-being. As Collins observes, dismissal from employment deprives the worker not only of their major source of income, but also leads to a loss of status. In some cases, the worker, deprived of 'membership of the most significant community in their life', suffers a personal impact akin to a criminal punishment. ${ }^{32}$ Dismissal without cause strikes at the personal integrity of the individual that is the root of Article 3.

Article 10 on freedom of thought, conscience and religion, corresponding to Article 9 ECHR, is of direct relevance in cases where termination of employment is in violation of the freedom to hold religious or other beliefs. ${ }^{33}$ Article 10 also interacts with Article 21 on non-discrimination on the ground of 'religion or belief'.

Article 12 on freedom of association, sourced from Article 11 ECHR, is also relevant. The essence of this freedom is the right of all workers, as autonomous human beings, to join and participate in trade unions that represent and protect their interests in the workplace. The autonomy of the worker to exercise the freedom to join a trade union, or not to join, ${ }^{34}$ is jeopardised if there is no protection against dismissal for this reason. Article 5 of ILO Convention No 158 on Termination of Employment identifies union membership or participation in union activities outside of working hours or, with the consent of the employer, within working hours, as not constituting valid reasons for termination. ${ }^{35}$

Article 15 on the freedom to choose an occupation and engage in work interacts closely with Article 30. Underlying Article 15, is the notion of an autonomous 'right to work' although not a right to work in a particular job. Unjustified termination of employment negates the individual's right to work and choice of occupation. ${ }^{36}$ It follows that laws on unjust dismissal should include a right to reinstatement or re-engagement in a comparable job as the most meaningful remedy to restore justice for the worker.

The relationship between Article 30 and Article 16, on freedom to conduct a business, is sensitive and ill-defined. Article 16 is sourced from the case law of the Court

\footnotetext{
${ }^{31}$ Ibid, 16-18.

${ }^{32}$ Ibid, 2.

${ }^{33}$ See ECtHR, Ivanova v Bulgaria [2007] no 52435/99.

${ }^{34}$ Young, James and Webster $\mathrm{v}$ United Kingdom [1981] nos 7601/76 and 7806/77.

${ }^{35}$ Art 5(a).

${ }^{36}$ See B Hepple, 'A Right to Work?' (1981) 10 ILJ 65 at 76-78.
} 
of Justice which has recognised the freedom to exercise an economic or commercial activity. ${ }^{37}$ It enshrines managerial authority as a corollary of economic freedom. Article 30 acts as a counterweight to Article 16 by limiting managerial authority to dismiss at will. Article 16, in common with Article 30, operates in accordance with Union law and national law and practices. Member States, therefore, have freedom to reconcile any conflict between Articles 16 and 30 so long as their rules are compatible with EU law and international obligations.

Article 17 on the right to property interacts with Article 30 only to the extent that it is accepted that there is an element of property ownership in the job for the individual worker. The right of the worker to protection against unjust dismissal implies that ownership of the job is not in the exclusive control of the employer. Article 30 does not, however, establish an unfettered right of the worker to 'own' or 'use' the job as a 'lawfully acquired possession' in the sense envisaged by Article 17. The concept of acquired property ownership rights is analogous to acquired employment rights in the context of the Transfers of Undertakings Directive, 2001/23. ${ }^{38}$

Article 21 on non-discrimination and Article 23 on equality between men and women provide specific reference points for the protection of workers whose employment relationship has been terminated by reason, respectively, of discrimination on one of the grounds referred to in Article 21, at least to the extent that these replicate the grounds in Article 19 TFEU, or in the specific violation of the principle of equal treatment between men and women. In practice Articles 21 and 23 are stronger than Article 30 because, unlike Article 30, these Charter rights flow directly from EU treaty provisions put into effect in the legal orders of the Member States by the transposition of directives and underpinned by the general principle of equality evolved by the Court of Justice.

Article 25 on the rights of the elderly intersects with Article 30. For many older workers the right to job security and to continue in work until a time of their own choosing, is important for their 'dignity' and 'independence' as expressed in Article 25 and recognised implicitly in Article 23 RESC. Once older workers cease working they may lose an integral part of their 'social and cultural life'. However, the Court of Justice has taken a somewhat converse view of the dignity of the older worker when upholding a national rule allowing for compulsory retirement at the age of 67 on the basis, in part, of accepting a rationale that such a rule 'makes it possible to avoid a situation in which employment contracts are terminated in situations which are humiliating for elderly workers'. 39

Article 26 on the integration of persons with disabilities is also highly relevant when evaluating Article 30. The opportunity to obtain work but also to maintain it with security is vital for the 'social and occupational integration' of persons with disabilities. Social inclusion through employment is at the core of the UN Convention on the Rights of Persons with Disabilities, which obliges State parties to prohibit discrimination on the

\footnotetext{
${ }^{37}$ The explanation on Art 16 refers to the following cases, inter alia: Case 4/73 Nold [1974] ECR 491, para 14; Case 230/78 Sp A Eridinia and others [1979] ECR 2749, paras 20-21; Case C-240/97 Spain v Commission [1999] ECR I-6571.

${ }^{38}$ Council Directive 2001/23/EC of 12 March 2001 on the approximation of the law of the Member States relating to the safeguarding of employees' rights in the event of transfers of undertakings, businesses or parts of undertakings or businesses, OJ L 82, 22.3.2001, p 16.

${ }^{39}$ Case C-141/11 Hörnfeldt, 5 July 2012, para 34.
} 
basis of disability with regard to 'all matters concerning all forms of employment', including 'continuance of employment'. ${ }^{40}$ The UN Convention has been approved by Council Decision $2010 / 48^{41}$ and, therefore, as the Court of Justice has recently observed in Ring and Werge, ${ }^{42}$ its provisions are, from the time of the entry into force of the Convention, an integral part of the EU legal order. It follows that the general nondiscrimination Directive, 2000/78, must, as far as possible, be interpreted in a manner consistent with the Convention. ${ }^{43}$ In that context, the Court of Justice proceeded to hold that Directive 2000/78 must be interpreted as precluding national legislation under which an employer can terminate the employment contract with reduced notice if a disabled worker has been absent because of illness, with his salary paid, for 120 days during the previous 12 months, where those absences are either the consequence of the employer's failure to take the appropriate measures in accordance with the obligation to provide reasonable accommodation, ${ }^{44}$ or, where those absences are the consequences of his disability, unless that legislation, as well as pursuing a legitimate aim, does not go beyond what is necessary to achieve that aim. ${ }^{45}$

Article 27 on the right of workers to information and consultation within the undertaking is concerned with the process of termination of employment and therefore interacts with Article 30 in the specific contexts of Directive 98/59 on collective redundancies and Directive 2001/23 on transfers of undertakings. ${ }^{46}$ More generally, Article 27 places emphasis on the importance of transparency and procedural fairness in the termination of employment even in circumstances where dismissal may be justified in substance. ${ }^{47}$

Article 28 on the right of collective bargaining and action interrelates with Article 30 in two ways. First, the individual worker facing the prospect of dismissal can secure representation from their trade union who will advocate on their behalf. Collective bargaining backed up by the ultimate threat of industrial action is also vital in preventing or reducing mass redundancies or mitigating their impact. The effectiveness of the interaction between Articles 28 and 30 is blunted somewhat, however, by the exclusion of the right to strike from the legal basis provisions in Article 153 TFEU. Second, those participating in collective bargaining require protection from dismissal. ${ }^{48}$

Article 33(2) is the only other right or principle in the Charter providing express protection from dismissal. It provides that 'everyone' shall have the 'right to protection

\footnotetext{
${ }^{40}$ Art 27a: http://www.un.org/disabilities/convention/conventionfull.shtml (adopted 13 Dec 2006).

${ }^{41}$ Council Decision 2010/48/EC of 26 November 2009, OJ L 23, 27.1.2010, p 35.

${ }^{42}$ Cases C-335 and 337/11, 11 April 2013, para 30.

${ }^{43}$ Council Directive 2000/78/EC of 27 November 2000 establishing a general framework for equal treatment in employment and occupation, OJ L 303, 2.12.2000, p 16. The UN Convention entered into force on 3 May 2008.

${ }^{44}$ Cases C-335 and 337/11 Ring and Werge, 11 April 2013, point 3 of the operative part of the judgment. The obligation to provide reasonable accommodation is laid down in Article 5 of Directive 2000/78, ibid.

${ }^{45}$ Ibid, point 4 of the operative part of the judgment.

${ }^{46}$ Council Directive 98/59/EC of 20 July 1998 on the approximation of laws of the Member States relating to collective redundancies, OJ L 225, 12.8.1998, p 16 (as corrected by Corrigendum, OJ L 59, 27.2.2007) and Council Directive 2001/23/EC of 12 March 2001 on the approximation of the law of the Member States relating to the safeguarding of employees' rights in the event of transfers of undertakings, businesses or parts of undertakings or businesses, OJ L 82, 22.3.2001, p 16.

${ }^{47}$ Collins, $\mathrm{n} 9$ above, at 104-140. See also, Arts 7-10 of ILO Convention No 158, n8 above.

${ }^{48}$ See Art 5(b) of ILO Convention No 158.
} 
from dismissal' for reasons connected with maternity, the right to paid maternity leave and parental leave following the birth or adoption of a child. As it is sourced directly from EU legislation, discussed in part A above, it places those workers who fall within its scope with a firm foundation of employment protection without the need to draw directly on Article 30.

Article 34 recognises the entitlement to social security and social assistance 'in the case of loss of employment'. It is a limited principle, mainly governed by national law, but it provides some recognition of the important role of social security in cushioning the worker against the worst effects of termination of employment in circumstances where it may be unexpected or unjustified or both.

Article 41(2) on the right of every person to be heard, the right to have access to his or her file, and the obligation of the Union to give reasons for its decisions, is important for EU civil servants seeking to rely directly on their right to a fair procedure in the event of their dismissal. Article 42 on the right of access to documents is also important in this respect. The Court of Justice, in Strack, ${ }^{49}$ has recently upheld the right of EU civil servants to expect their institutional employer to observe both procedural and substantive employment rights in the Charter when applying the Staff Regulations in accordance with Article 51(1).

Finally, Article 47 on the right to an effective remedy and to a fair trial is emerging as a significant dimension of the right to protection against unjustified dismissal. First, the worker who succeeds in establishing unjustified termination within the scope of EU law is entitled to an effective remedy including the possibility of reinstatement in the job or re-engagement or, if this is not practicable or possible, to be awarded adequate compensation. Second, Article 24 RESC provides that a right to appeal to 'an impartial body' is an essential part of the protection of the claim of a worker who considers that their employment has been terminated without a 'valid reason' ${ }^{50}$ It follows that the right to be given a valid reason for dismissal is essential for the protection of civil rights and the entitlement of the worker seeking redress to a fair hearing by a tribunal guaranteed by Article 6 ECHR, which is a primary source of Article 47..$^{51}$

\section{Sources of Article 30 Rights}

\section{ECHR}

The ECHR is not a direct source of Article 30 but there are a number of connections between its provisions and the rights of workers on termination of employment. Article 6 of the Convention has acquired particular significance. In a series of cases the European Court of Human Rights has gradually extended the applicability of the right to an effective remedy and a fair trial to labour disputes concerning civil servants. ${ }^{52}$ For the Strasbourg Court, judicial protection is not effective if there is a procedural or substantive

\footnotetext{
${ }^{49}$ Case C-579/12 RX-II European Commission v Strack (19 Sept 2013).

${ }^{50}$ This is a reference to the distinction between valid and invalid reasons for dismissal contained in ILO Convention No 158 discussed in CIII.

${ }^{51}$ See ECtHR, K.M.C. v Hungary, ECtHR [2012] no 19554/11.

${ }^{52}$ Frydlender v France [2000] no 30979/96, Vilho Eskelinen and Others v Finland [2007] no 63235/00 and Iordanov and Others v Bulgaria [2009] no 23530/02.
} 
obstacle to a genuine judicial examination of the merits of the parties' claims. ${ }^{53}$ This approach applies in assessing the fairness of proceedings concerning removal of civil servants from office or the excessive length of dismissal proceedings. ${ }^{54}$ Rights on termination of employment have also been recognised in cases involving Article 9 ECHR on freedom of religion, ${ }^{55}$ and, latterly, upholding the rights of 'whistleblowers' to protection from dismissal without notice for exercising their freedom of expression under Article 10 ECHR. ${ }^{56}$ In cases involving discriminatory dismissal, Article 14 ECHR and Protocol 12, where connected to another provision of the ECHR, are also engaged.

In the recent case of K.M.C v Hungary, ${ }^{57}$ the European Court of Human Rights has held that the dismissal of a civil servant without giving reasons, permitted under Hungarian law at the time of the case, meant that the dismissal could not be practically and effectively challenged independently in a hearing before an impartial tribunal contrary to Article 6 ECHR. ${ }^{58}$ The same conclusion had already been reached by the Hungarian Constitutional Court, ${ }^{59}$ which annulled the offending domestic legislation on similar grounds after the application had been made to Strasbourg. Significantly, the European Court of Human Rights referred expressly to Article 30 of the Charter in its judgment and noted that it draws on Article 24 RESC. ${ }^{60}$

\section{UN Treaties}

Article 6 of the UN International Covenant on Economic, Social and Cultural Rights (ICESCR) recognises the 'right to work' including 'the right of everyone to the opportunity to gain his living by work which he freely chooses or accepts'. ${ }^{61}$ State parties are required to 'take appropriate steps to safeguard this right' and to ensure its progressive realisation. In General Comment No 18 on the Right to Work, ${ }^{62}$ the UN Committee on Economic, Social and Cultural Rights (UNCESR) noted that the right to work implies the 'right not to be unfairly deprived of employment'. ${ }^{63}$ The normative content of the right incorporates ILO Convention No 158, discussed below. ${ }^{64}$ The UN Committee regards the failure to protect workers against unfair dismissal as a violation of the obligation on State parties to protect the right to work. ${ }^{65}$

\section{ILO}

\footnotetext{
${ }^{53}$ See the decision of the Hungarian Constitutional Court, no 8/2011, cited affirmatively by the ECtHR in K.M.C. v Hungary [2012] no 19554/11, para 16.

${ }^{54}$ Hraldo v Croatia [2011] no 23272/07, Mishgjoni v Albania [2010] no 18381/05 and Golnja v Slovenia [2006] no 76378/01.

${ }^{55}$ Ivanova v Bulgaria [2007] no 52435/99.

${ }^{56}$ Heinisch v Germany [2010] no 28274/08.

${ }^{57}$ K.M.C. v Hungary [2012] no 19554/11.

${ }^{58}$ Ibid, paras 33-36.

${ }^{59}$ Hungarian Constitutional Court, no 8/2011.

${ }^{60}$ K.M.C. v Hungary [2012] no 19554/11, paras. 18-19.

${ }^{61}$ Adopted on 16 Dec 1966: http://www.ohchr.org/EN/ProfessionalInterest/Pages/CESCR.aspx.

${ }^{62} \mathrm{E} / \mathrm{C} 12 / \mathrm{GC} / 18,6$ Feb 2006: http://tb.ohchr.org/default.aspx?Symbol=E/C.12/GC/18.

63 Ibid, para 6.

${ }^{64}$ Ibid, para 11.

${ }^{65}$ Ibid, para 35.
} 
Article 30 can ultimately be traced back to two ILO instruments on termination of employment at the initiative of the employer, Recommendation No 119, 1963 - now replaced by Recommendation No 166, 1982 - and Convention No 158, 1982. ${ }^{66}$ The original non-binding Recommendation provided the foundation of the principle that termination of the employment relationship by the employer should not take place without a valid reason and also the right of a worker to appeal against that termination to an independent body. It spurred legislation to protect job security in many EU Member States. ${ }^{67}$ However, it was the adoption of the Convention, as a stronger normative measure, that began the process of elevating protection against unjustified dismissal to the level of an international human right. ${ }^{68}$ The main provisions are briefly outlined below but will be analysed in more depth in part DIII.

Article 4 of the Convention provides that:

The employment of a worker shall not be terminated unless there is a valid reason for such termination connected with the capacity or conduct of the worker or based on the operational requirements of the undertaking, establishment or service.

The Convention identifies specific reasons for termination that are not valid, including: union membership or participation in union activities; seeking office or acting as a workers' representative; filing a complaint or taking proceedings against an employer; race, colour, sex, marital status, family responsibilities, pregnancy, religion, political opinion, national extraction or social origin; absence from work during maternity leave; and temporary absence from work because of illness or injury. ${ }^{69}$ Age is regarded as an invalid reason in paragraph 5 of the replacement Recommendation but it is not referred to in the Convention.

The substantive right to protection is backed up by procedural rights of the worker to a defence prior to, or at the time of, termination and a right of appeal against termination to an independent body, which can declare the dismissal invalid and remedy the situation by reinstatement, adequate compensation or other relief. ${ }^{70}$ The issue of remedies is considered further in part DV.

Under Article 2 of the Convention ratifying States have flexibility to exclude three categories of workers from some of the provisions. The excluded categories are:

a) workers engaged on contracts of employment for a specified period of time or a specified task;

b) workers serving a period of probation or a qualifying period of employment, 'determined in advance and of a reasonable duration';

c) workers engaged on a casual basis for a short period.

The impact of these limitations is discussed in DIV below, in particular the length of a 'reasonable' qualifying period, but there is no doubt that by excluding these categories of workers, who are among the most vulnerable, the right is significantly impaired for many.

\footnotetext{
${ }^{66}$ ILO instruments can be found on the NORMLEX database: http://www.ilo.org/dyn/normlex/en.

${ }^{67}$ E Yemin, 'Job Security: influence of ILO standards and recent trends' (1976) 13 International Law Review 17.

${ }^{68}$ See B Napier, 'Dismissal - The New ILO Standards' (1983) 12 Industrial Law Journal 17.

${ }^{69}$ Arts 5-6.

${ }^{70}$ Arts 7-10.
} 


\section{Council of Europe Treaties}

Article 1 ESC contains certain obligations on the contracting parties aimed at ensuring the 'effective exercise of the right to work' but these obligations have not been interpreted by the European Committee of Social Rights (ECSR) as including protection for workers against unjust dismissal except in instances of discrimination. ${ }^{71}$

The main source of Article 30 is Article 24 RESC on the right to protection in cases of termination of employment at the initiative of the employer. This provision is based on ILO Convention No 158 and is intended to bring the Council of Europe regime in line with the ILO to avoid double standards. Article 24 RESC is worded as follows:

With a view to ensuring the effective exercise of the right of workers to protection in cases of termination of employment, the Parties undertake to recognise:

a. the right of all workers not to have their employment terminated without valid reasons for such termination connected with their capacity or conduct or based on the operational requirements of the undertaking, establishment or service;

b. the right of workers whose employment is terminated without a valid reason to adequate compensation or other appropriate relief.

To this end the Parties undertake to ensure that a worker who considers that his employment has been terminated without a valid reason shall have the right to appeal to an impartial body.

The Appendix to the RESC contains the same list of invalid reasons for termination of employment as Article 5 of the ILO Convention and also the same exceptions including the option for the contracting parties to introduce or maintain a qualifying period for a 'reasonable duration' before the right to bring a claim can be exercised.

In its case law, the ECSR has interpreted the core right in Article 24 RESC broadly and the exceptions strictly. As the content of Article 30 is based primarily on the right contained in Article 24 RESC the relevant case law will be discussed in the analysis in part $\mathrm{D}$ below.

V National constitutional laws

Article 30 is not sourced directly from national constitutional laws. Many provisions common to national constitutions, such as dignity, equality, non-discrimination and the right to a fair trial and an effective remedy, are relevant, but will not be discussed in detail in this chapter. It is important to note, however, that legislation on unjust dismissal in some Member States, and related laws, have been interpreted by national constitutional courts purposively to guarantee effective protection. For example, legislation in Germany and Scandinavia has been interpreted and applied by the courts to protect employee representatives from dismissal by guaranteeing fair procedures. ${ }^{72}$

\footnotetext{
${ }^{71}$ Digest of the Case Law of the European Committee on Social Rights, 1 Sept 2008, pp 19-25: http://www.coe.int/t/dghl/monitoring/socialcharter/digest/DigestSept2008_en.pdf

${ }^{72}$ See S Anderman, 'Termination of Employment: Whose Property Rights?' in C Barnard, S Deakin and G S Morris (eds), The Future of Labour Law (Oxford, Hart, 2004) 101-128 at 123; and B Hepple, 'European Rules on Dismissals Law?' (1997) Comp Labour Law J 204 at 210-12.
} 
Article 18 of the Italian Statuto di Lavoratori ${ }^{73}$ is of particular interest. It has been associated with the concept of strong stability in the employment relationship to limit the power of dismissal. This concept has been constructed in the post-1945 period and recognised by the Constitutional Court when interpreting the Statuto. ${ }^{74}$ In its original version, the Statuto provided that if a worker claimed unfair dismissal, there was a right to interim relief until the tribunal decided the case. Enterprises or organisations employing more than 15 persons were required to reinstate the unjustly dismissed worker in the job and penalties could be imposed for failure to comply. ${ }^{75}$ Wedderburn described the Statuto as a version of 'habeas corpus for the worker'. ${ }^{76}$ Anderman regarded it as forcefully imposing responsibility on the employer not to dismiss without an independent assessment rather than necessarily creating a property right in the job. ${ }^{77}$ Until recently, attempts to modify the legislation had met with strong, sometimes violent, opposition. Significantly, however, a reform law was adopted in 2012, which makes certain procedural changes but, most importantly, ends obligatory reinstatement as the only remedy for unjustified dismissal in most cases involving employers with more than 15 workers by providing for compensation in the range of one to two years' pay as an alternative. ${ }^{78}$ Whilst such a revision has almost certainly only been possible because of the economic crisis, the revised Article 18 remains among the most protective provisions on job security in the laws of the Member States.

\section{Analysis \\ I General Remarks}

Article 30 carries with it connotations of a property right in the job for the worker, or at least a shift in that direction. Whilst there is much to support this analysis, it is more accurate to understand the right as a mechanism for adjusting the employer-worker power relationship. Protection against unjustified dismissal places limits on the exercise of ownership rights by the employer but it does not create property rights for the worker in a particular job. ${ }^{79}$ The main challenge for legislators and judges, when evaluating Article 30 , is to find the right balance between the employer's managerial prerogative to make business decisions and the worker's reasonable expectation of job security. The balance of interests was summarised by the ILO's Committee of Experts on the Application of Conventions and Recommendations (CEACR) in its 1974 General Survey on Recommendation No $119:^{80}$

\footnotetext{
${ }^{73}$ Law no 300/1970.

${ }^{74} \mathrm{~S}$ Bellomo, 'Italian Report'. Draft paper presented at the Seminar of Comparative Labour Law

'Pontignano XXX', Modena, 16-19 July 2013. See Case no 174, 12 December 1972.

${ }^{75}$ Anderman, above $\mathrm{n} 72$ at 122-23.

${ }^{76}$ Lord Wedderburn, 'The Italian Workers Statute: British Reflections on a High Point of Legal Protection' (1990) 19 ILJ 154.

77 Anderman, above $\mathrm{n} 72$ at 123.

${ }^{78}$ Law no 92/2012. See Bellamo, above n74. I am very grateful to Stefano Bellomo and Massimiliano Delfino for their advice on the labour law reforms in Italy.

${ }^{79}$ See Anderman, above $\mathrm{n} 72$.

${ }^{80}$ ILO GS 1974 on the reports related to Recommendation No 119, para 3.
} 
Although the Recommendation is essentially intended to provide protection of the worker's security of employment, it also embodies an attempt to balance the several interests involved: that of the worker in job security, since the loss of his job may mean loss of his and his family's livelihood; that of the employer in retaining authority over matters affecting the efficient operation of the undertaking, that of the community in maintaining peaceful labour relations and avoiding unnecessary dislocations due to either unemployment or unproductive economic units.

In seeking to find this balance the need for a 'valid reason' for dismissal is paramount. As we have seen, the obligation on the employer to provide a valid reason for dismissal, and the listing of reasons that are automatically deemed not valid, is derived from Articles 4 and 5 of ILO Convention No 158 and reinforced by Article 24 RESC. The CEACR regards the Convention's provisions as establishing a 'fundamental principle of justification' for terminating employment relationships of indefinite duration $^{81}$ and, more radically, it advises that the Convention removes the possibility for 'unilateral' termination by means of a period of notice or compensation in lieu. ${ }^{82}$

The judgment of the European Court of Human Rights in K.M.C. v Hungary ${ }^{83}$ is significant in highlighting the incidental application of the 'fundamental principle of justification' for dismissal in the context of broader civil and political rights and freedoms guaranteed under the ECHR and having the same meaning and scope in the Charter. The right to a fair hearing in Article 6 ECHR requires a reason - implicitly a valid reason - for dismissal to be communicated to the worker in order for that right to be practical and effective. ${ }^{84}$ Rights to freedom of religion, freedom of expression, freedom of association and non-discrimination, in Articles 9, 10, 11 and 14 ECHR, among others, will be violated if there is interference with the exercise of these civil rights. Such interference will be present in cases where the exercise of the right in question carries with it the sanction of unilateral termination of employment. Similarly, it must follow from this reasoning, that the right to an effective remedy under Article 13 ECHR requires reinstatement or adequate compensation in lieu.

Also, it can be argued that by referring to both Article 30 and Article 24 RESC, and noting that the latter is the source of the former in the explanations, ${ }^{85}$ the European Court of Human Rights is sending a message that the effect of incorporating Article 30 into the Charter, and granting the Charter the same legal value as the Treaties under Article 6(1) TEU, is to create an obligation on all EU Member States, as members of the Council of Europe, to guarantee the right to protection in cases of termination of employment regardless of whether or not those States have ratified the RESC.

Judge Pinto de Albuquerque is more explicit in a separate concurring opinion issued with the judgment. In his opinion, the effect of the adoption of Article 30 and the explanations has been to reinforce a European 'consensus' on protection in cases of termination of employment amounting to a 'positive obligation for the Contracting Parties to the Convention to implement the principle of justification for termination of employment'. ${ }^{86}$ The Court had previously established that a social right can be legitimately derived from a Convention provision 'even when such a right is foreseen in

${ }^{81}$ CEACR Direct Request - Luxembourg (2007).

${ }^{82}$ CEACR General Survey - Protection against unjustified dismissal (1995), para 76.

${ }^{83}$ K.M.C. v Hungary [2012] no 19554/11.

${ }^{84}$ Ibid, paras 33-35.

${ }^{85}$ Ibid, paras 18-19.

${ }^{86}$ Ibid, separate opinion, $\mathrm{p} 20$. 
the [ESC] and the Contracting Party is not bound by the relevant provision of the [ESC]'. ${ }^{87}$ Referring also to Article 6 ICESCR and ILO Convention No 158, he concludes that it is 'not acceptable' for one State to advocate a 'double standard' in respect of termination of employment in respect of different international organisations. ${ }^{88}$

The Judge's opinion amounts to a robust assertion of the 'fundamental principle of justification' in the European human rights context. It explains the basis upon which the European Court of Human Rights was able to make interconnections between Article 30, Article 24 RESC and Article 6 ECHR, so as to require Hungary to provide civil servants with valid reasons for termination of their employment that were capable of independent legal challenge.

K.M.C. v Hungary demonstrates the potential of what Kahn-Freund once described as the 'reflex effect' of proclaiming fundamental social rights, as in the case of Article 30, as a basis for 'the interpretation of positive legal norms and as direct sources of rights' ${ }^{89}$ However, reflexive interpretation requires the existence of a positive legal norm. The legal vacuum in the EU and the limitations of Article 30 in the legal orders of the Member States has been starkly demonstrated in Nagy, ${ }^{90}$ a follow-up case to K.M.C. v Hungary referred directly to the Court of Justice by a Hungarian court in October 2012, some three months after the European Court of Human Rights had given judgment.

Nagy concerned a group of Hungarian civil servants who had been removed from office without cause under the same law adjudicated in K.M.C. v Hungary, which permitted termination of employment in the civil service 'without justification'. The civil servants were dismissed prior to the annulment of the law by the Constitutional Court in May 2011. The Hungarian court referred the case to the Court of Justice on the basis that Article 30 'has direct effect in terms of its applicability' and it was therefore seeking guidance on the scope of the right, including the need to notify the worker of the reason for the dismissal and the existence of a remedy. Not surprisingly, the Court of Justice, in a brief Order, ruled that it did not have jurisdiction. The national court was incorrect in assuming that Article 30 had direct effect and had misunderstood Article 51. The Court of Justice noted that the orders for reference did not contain any evidence that the proceedings 'concern the interpretation or application of a rule of the Union other than those contained in the Charter' and did not concern the implementation of EU law within the meaning of Article 51. The invocation of provisions of the Charter could not, alone, establish competence on the Court of Justice to answer questions from the national court. $^{91}$

The finding of the Court of Justice is axiomatic but it lays bare just how limited the Court of Justice is as a human rights court in the absence of a direct connection between EU law and a Charter right. It is therefore important to consider relevant case law of the Court of Justice in two examples where EU law has the potential to offer a degree of protection to individual workers in the event of termination of their employment contract or relationship and Article 30 has the potential to be useful.

\footnotetext{
${ }^{87}$ Ibid, citing Demir and Baykara v Turkey [2008] no. 34503/97, paras 153-154.

${ }^{88}$ Ibid, p 21.

${ }^{89}$ O Kahn-Freund, 'The European Social Charter' in F G Jacobs (ed), European Law and the Individual (Amsterdam, North Holland, 1976) 181-211 at 184.

${ }^{90}$ Cases C-488-491/12 and 526/12 Nagy and others, Order of the Court, 10 Oct 2013.

91 Applying Case C-617/10 Åkerberg Fransson, 26 Feb 2013.
} 
The first example, the Transfers of Undertakings Directive, 2001/23, ${ }^{92}$ outlined in part $\mathrm{A}$, is largely bereft of the language of rights, but it does recognise, implicitly, important elements of the evolving right of protection in circumstances where dismissal can be deemed unfair or unjust. It upholds the right of an employee to job security in situations where an employer might otherwise be free to carry out dismissals at will in order to sell or sub-contract the business subject only to following certain procedural obligations laid down under national laws or practices. ${ }^{93}$ More radically, by restricting the possibilities for dismissal, it allows for certain rights, such as pay and conditions that have been acquired over time by the employee, including by means of collective agreements, to be transferred with the employee to the new employer. The notion that such rights have been acquired and should not be forfeited, even in the event of termination of the original contract, is capable of being interpreted as a conceptualisation of the right to protection against unjust dismissal that transcends job security and recognises, in this particular context, the job itself as a property right, or stake, owned by the employee.

The Court of Justice has not been asked to rule in a case on Directive 2001/23 concerning a potential violation of Article 30. However, in Alemo-Herron, ${ }^{94}$ it gave precedence to an employer's freedom to conduct a business under Article 16 in a fashion that weakens the protection of acquired rights. The case concerned the contracting out of leisure services by an English local authority to a private company which, two years later, sold its business to another company, Parkwood. Pay was determined by a national collective agreement renewed periodically. The question arose as to whether Parkwood were bound by the national collective agreement as they had not been a party to the negotiations. Advocate General Cruz Villalón supported a dynamic interpretation suggested by the UK Supreme Court under which the transferee is bound under the English law of contract not only by collective agreements in force at the time but also subsequent to that transfer. The Advocate General noted that the freedom to conduct a business in Article 16 is not an absolute right and is 'very much open to being used as a counterweight' to other fundamental rights. ${ }^{95}$ The logic would suggest that, at the very least, a balance should be struck between Article 16 and fundamental social rights in the Charter. By contrast, the Court of Justice, relying heavily on the principle of contractual freedom in Article 16, preferred a static interpretation of acquired rights on the basis that requiring the transferee to be bound by a contractual process to which he is not a party seriously reduces the employer's contractual freedom 'to the point that such a limitation is liable to adversely affect the very essence of its freedom to conduct a business'. ${ }^{96}$

The Court of Justice's judgment is understandable if Article 16 is considered in isolation. As the employees in question had not had their contracts terminated the application of Article 30 did not arise directly. However, taking into account the

\footnotetext{
${ }^{92}$ Council Directive 2001/23/EC of 12 March 2001 on the approximation of the law of the Member States relating to the safeguarding of employees' rights in the event of transfers of undertakings, businesses or parts of undertakings or businesses, OJ L 82, 22.3.2001, p 16.

${ }_{93}^{93}$ See Article 4 discussed in part A above.

${ }_{94}^{94}$ Case C-426/11 Alemo-Herron and Others v Parkwood Leisure Ltd, 18 July 2013.

${ }^{95}$ Ibid, opinion, para 52.

${ }^{96}$ Ibid, judgment, para 35. The Court of Justice, unlike the Advocate General, was not prepared to distinguish Case C-499/04 Werhof [2006] ECR I-2397, where a static interpretation was preferred in the context of the contractual system in Germany.
} 
objectives of the Directive, it should have been considered as a 'counterweight' to Article 16. The employees had only been able to keep their jobs because the Directive is designed to guarantee 'the protection of employees in the event of a change of employer, in particular, to ensure that their rights are safeguarded' ${ }^{97}$ At the very least, the Court should have taken account of the balance between the commercial interests of the company inheriting the transferred employees and the protection afforded to those employees to retain their acquired rights under established collective bargaining processes. Flexible methods of contractual interpretation, which are the norm under UK law, would have allowed for a dynamic approach without fundamentally restricting economic freedom.

The second example, the Collective Redundancies Directive, $98 / 59,{ }^{98}$ previously referred to in part $\mathrm{A}$, is relevant to Article 30 because it relates to termination of employment based on the 'operational requirements' of the undertaking, establishment or service falling within Article 4 of ILO Convention No 158 and Article 24 RESC. Whilst a dismissal for economic reasons would not normally involve disrespect or indignity for the worker, Article 30 is potentially engaged because it is essential, in the interests of justice in dismissal, for a fair procedure to be followed and objective criteria applied in the selection of workers to be made redundant. ${ }^{99}$

One immediate issue is the relationship between individual and collective dismissals. Under Article 1(a) of the Directive, the term 'collective redundancies' means 'dismissals effected by the employer for one or more reasons not related to the individual workers'. ${ }^{100}$ Article 6 places a duty on Member States to ensure that judicial and/or administrative procedures for the enforcement of 'obligations' under the Directive are available to the workers' representatives and/or workers.

The possible application of Article 30 in this context has arisen in two cases before the Court of Justice. ${ }^{101}$ In the first case, Mono Car Styling, ${ }^{102}$ Advocate General Mengozzi, in the only substantive evaluation of Article 30 to date in proceedings before the Court of Justice, briefly considered its potential relevance in the context of the Collective Redundancies Directive. In his opinion, the underlying purpose of the EU's legislature, by eschewing the language of 'rights' and preferring to refer instead to 'obligations', is 'not to bestow a series of rights on those affected by collective redundancies, but to impose a series of obligations on employers who decide to make such redundancies'. ${ }^{103}$ It follows, according to the Advocate General, that Article 30 does not require an individual right of action to be provided in any case in the event of an employer failing to observe the information and consultation procedure. ${ }^{104}$ In his assessment, the reference to protection against 'unjustified' dismissal in Article 30 is an

\footnotetext{
${ }^{97}$ Recital 4 of the preamble of Directive 2001/23.

${ }^{98}$ Council Directive 98/59/EC of 20 July 1998 on the approximation of laws of the Member States relating to collective redundancies, OJ L 225, 12.8.1998, p 16 (as corrected by Corrigendum, OJ L 59, 27.2.2007).

${ }^{99}$ Collins above $\mathrm{n} 9$ at 153.

${ }^{100}$ Emphasis added.

${ }^{101}$ Case C-12/08 Mono Car Styling SA v Dervis Odemis and Others [2009] ECR I-6653 and Case C-323/08 Ovidio Rodriguez Mayor and Others v Herencia yacente de Rafael de las Heras Dávila and Others [2009] ECR I-11621.

${ }^{102}$ Case C-12/08, ibid.

103 Opinion, ibid, para 44.

${ }^{104}$ Ibid, para 96.
} 
important 'qualification' which 'makes clear' that the protection of every worker is not provided, 'as a fundamental individual right, with respect to every kind of irregularity that a dismissal might involve'. ${ }^{105}$ Instead, to invoke Article 30 within the scope of EU law, there must be a 'serious irregularity' as might arise, for example, in relation to the actual merits of the decision to dismiss. The Advocate General concluded that: ${ }^{106}$

Breaches of Directive 98/59, on the other hand, do not appear such as to justify reference to Article 30 of the Charter for, given the content of the directive, it is intended that the result of such breaches will be illegality of a formal/procedural kind.

Advocate General Mengozzi's narrow interpretation of Article 30 would, effectively, exclude formal or procedural irregularities in the information and consultation process from the scope of unjust dismissal, an approach that is out of line with Articles 13-14 of ILO Convention No 158. In an observation on Convention the CEACR has commented that: ${ }^{107}$

Terminations of employment for economic, technological, structural or similar reasons must be consistent with the provisions of Article 13 and 14 of the Convention, particularly in respect of the consultation of worker's representatives and notification to the competent authority.

In the second case, Mayor, ${ }^{108}$ a group of employees had their contracts of employment terminated as a result of the death of their employer. The effect of Spanish law was to place the employees of a natural person in a weaker position than the employees of a company as the former were regarded as not being dismissed in the event of the death of the employer. The national court asked if the Spanish legislation infringed Article 30. The case appeared to provide an ideal opportunity to interpret Article 30 in the context of the implementation of EU law within the field of application of the Charter under Article 51. However, the Court of Justice ruled that the dismissals could not be classified as a 'collective redundancy' because the provisions of Directive 98/59 presupposed the existence of an employer who contemplated redundancies and was capable of carrying out the required information and consultation process to put into effect such redundancies. ${ }^{109}$ It followed that the dispute was outside of the scope of the Directive and it was 'not necessary' to answer the question about the application of Article $30 .{ }^{110}$

The Court of Justice's reasoning in Mayor is highly questionable. Post-Lisbon the Court should have considered whether a literal interpretation of the wording of the Directive was compatible with the Charter as Treaty-equivalent law rather than treating Article 30 as an afterthought. ${ }^{111}$ The difference of treatment under Spanish legislation between workers who have their contracts terminated due to the death of their employer

\footnotetext{
${ }^{105}$ Ibid, para 97.

106 Ibid.

${ }^{107}$ CEACR observation - Cameroon (2007).

${ }^{108}$ Case C-323/08 Ovidio Rodriguez Mayor and Others v Herencia yacente de Rafael de las Heras Dávila and Others [2009] ECR I-11621.

${ }^{109}$ Ibid, para 42.

${ }^{110}$ Ibid, para 59.

${ }^{111}$ For an example of a purposive approach to interpretation see the Opinion of Advocate General Kokott in Case C-236/09 Association Belge des Consommateurs Test-Achats ASBL and Others, 30 Sept 2010.
} 
and workers who face dismissal due to corporate restructuring or insolvency is stark but deemed to be outside the scope of EU law.

\section{Scope of Application}

Under Article 30 the right to protection against unjustified dismissal applies to 'every worker' without qualification. Use of the broader term 'worker' rather than 'employee' is indicative of an inclusive approach to fundamental social rights in the EU that appears to encompass not only employees with a regular contract of employment but also nonstandard workers including casual workers, 'zero hours' workers, home workers, temporary agency workers and others who are not self-employed but may not have a contract of employment recognised under national law. ${ }^{112}$ Non-standard workers are in the most precarious position and are vulnerable to arbitrary dismissal.

Appearances are deceptive. Article 30 applies only 'in accordance with Union law and national law and practices'. In the course of this chapter the term 'worker' has been used in preference to 'employee' consistent with Article 30 and an inclusive interpretation of ILO Convention No 158 and Article 24 RESC. However, although the ILO Convention 'applies to all branches of economic activity and all employed persons ${ }^{113}$ both it, and the appendix to the RESC, permit States to exclude 'workers engaged on a casual basis for a short period'. ${ }^{114}$

Where the term 'employee' has been used in this chapter it has referred to EU or national legislation that is limited to employees as defined under national law. The Transfers of Undertakings Directive is a good example. Article 2(1)(d) of the Directive restricts its scope to 'any person who, in the Member State concerned, is protected as an employee under national law' (emphasis added). Whist the term 'worker' is used in EU health and safety legislation and some labour law directives, the personal scope of EU labour law is subject to a strong form of vertical subsidiarity which leads to a lack of legal coherence and contrasts with the development by the Court of Justice of a horizontal application of the concept of a 'worker' for the purposes of establishing the personal scope of core free movement provisions and gender equality law. ${ }^{115}$ In the absence of harmonisation of the concepts of 'employee' and 'worker' at EU level ${ }^{116}$ - or their replacement with an all-embracing 'personal employment contract' ${ }^{117}$ - protection against unjustified dismissal will be reserved mainly to the standard employee and the two-tier labour market will persist.

With regard to the scope of application more generally, the Charter requires consistent interpretation of the ECHR under Article 52(3), which is important bearing in mind the interconnections between ECHR rights and protection against termination identified by the European Court of Human Rights. It contains no information, however, on how to interpret the ESC, the RESC or ILO instruments. The ECSR has provided extensive guidance on the scope of the RESC. It is reasonable to expect that this guidance will, at least, be persuasive bearing in mind the direct reference to Article 24 RESC in the

\footnotetext{
${ }^{112}$ See M Freedland, 'From the Contract of Employment to the Personal Work Nexus' (2006) 35 ILJ 1 at 9.

113 Art 2(1) of ILO Convention No 158.

114 Ibid, Art 2(2)(c).

115 See Case C-256/01 Allonby v Accrington and Rossendale College [2004] ECR I-873.

${ }^{116}$ For some suggestions on how to achieve this, see Kenner, $\mathrm{n} 8$ above.

117 See M Freedland, The Personal Employment Contract (Oxford, Oxford University Press, 2003).
} 
explanations. ${ }^{118}$ The fact that this linkage was emphasised by the European Court of Human Rights in K.M.C. v Hungary, ${ }^{119}$ discussed in DI above, is important. It should point to a consistent interpretation of Article 24 RESC and Article 30 on the basis that all Member States are committed to upholding the Charter regardless of whether or not they have ratified the RESC. It is an approach that is necessary to ensure coherence in European human rights law and avoid a 'double standard'. ${ }^{120}$

\section{Specific Provisions}

Judge Pinto de Albuquerque, in his separate opinion in K.M.C. v Hungary, offers a summary of the 'minimum content in European human rights law' of the right to protection in the event of termination of employment that provides a useful template for its application in the context of EU law and the laws of the Member States. The right to protection consists of four 'core requirements' according to the Judge: ${ }^{121}$

[1] a formal written notice of termination of employment given to the employee,

[2] a pre-termination opportunity to respond given to the employee,

[3] a valid reason for termination, and

[4] an appeal to an independent body [with] powers to verify the factual and legal aspects of the appealed decision and to remedy it, if it is found illegal.

Termination of employment under ILO Convention No 158 and Article 24 RESC means termination at the initiative of the employer. ${ }^{122}$ This effectively excludes terminations by mutual consent and terminations on the initiative of the worker by reason of the employer's conduct or what is known as 'constructive dismissal' under UK law. ${ }^{123}$

Starting first with the requirement for notice for dismissal, there has been some useful guidance from the CEACR. According to the CEACR, the purpose of the formal written notice is to enable the worker to prepare himself to adapt to the situation and look for a new job. ${ }^{124}$ Article 11 of the Convention provides that such a period of notice must be of a 'reasonable' duration. The specific length of notice is left to national legislation. Compensation in lieu is possible but it must correspond to the remuneration the worker would have received during the period of notice. ${ }^{125}$ The only exception to the obligation to give notice is the case of serious misconduct by the worker. ${ }^{126}$

Next, procedural fairness prior to termination is founded on the right to a defence contained in Article 7 of the Convention. This is essential to allow workers to be heard by the employer and to ensure that any decision to terminate is preceded by dialogue and

\footnotetext{
118 See B Hepple, 'The EU Charter of Fundamental Rights' (2001) 30 ILJ 225 at 226.

119 [2012] no 19554/11.

120 Ibid, separate concurring opinion of Judge Pinto de Albuquerque discussed in D I above.

121 Ibid.

${ }^{122}$ CEACR General Survey 1995, para 19: http://www.ilo.org/global/standards/applying-and-promotinginternational-labour-standards/general-surveys/lang--en/index.htm

${ }^{123}$ Employment Rights Act 1996, s95(1)(c).

${ }^{124}$ CEACR Note on Convention No 158 and Recommendation No 166 concerning termination of employment, 2009, p 3: http://www.ilo.org/dyn/eplex/termmain.home?p_lang=en

125 CEACR GS 1995, para 247.

${ }^{126}$ CEACR direct request - Serbia (2006).
} 
reflection between the parties. ${ }^{127}$ The Recommendation envisages the issuance of a warning prior to termination and is more specific in requiring consultation with workers' representatives before a final decision is taken and making provision for the worker to be represented when defending himself. ${ }^{128}$

The requirement for a 'valid reason' or justification for termination is regarded as a fundamental principle and the "cornerstone" ${ }^{129}$ of the substantive right in Article 4 of the Convention and Article 24 RESC. The first valid reason identified is 'capacity' of the worker either due to a lack of skills or qualities necessary to perform certain tasks or poor work performance not caused by intentional misconduct.

In making decisions on the basis of the capacity of the worker, employers must ensure that they do not violate the principle of non-discrimination in Article 23 of the Charter and Directive 2000/78. The Court of Justice, in its judgment in Ring and Werge ${ }^{130}$ has taken a very broad view of the concept of 'disability' consistent with the UN Convention, discussed in part B above, ${ }^{131}$ and therefore protection in this respect is stronger than under the ILO Convention and the RESC. ${ }^{132}$

More problematic is age discrimination where a decision to terminate on grounds of age can be justified under Article 6 of Directive 2000/78 if 'objectively and reasonably justified by a legitimate aim, including legitimate employment policy, labour market and vocational training objectives, and if the means of achieving that aim are appropriate and necessary'.

In a series of cases, the Court of Justice has upheld mandatory retirement ages permitted under national legislation on the basis of employment policies aimed at sharing employment opportunities among the generations, ${ }^{133}$ and, in a recent case, backing this up with a reference to the right to work in Article 15 of the Charter. ${ }^{134}$ In Prigge, ${ }^{135}$ a mandatory requirement for airline pilots to retire at the age of 60 was struck down as disproportionate because it took no account of the capability of the individuals concerned and the reasons given, including the safety of passengers, were not sufficiently connected to the labour market.

\footnotetext{
${ }^{127}$ CEACR GS 1995, para 148. See also the application of Article 7 of the Convention by the Brussels Labour Court in DD v SA Vanduc-Topfilm, 20 Feb 1992, Roll No 79-759/91: 
Article 30 was not considered by the Court of Justice in these cases. Guidance from the CESR suggests that Contracting Parties to the RESC have a wide discretion to impose a 'valid retirement age' justified by the operational requirements of the undertaking, establishment or service. Age is not listed as an invalid reason for dismissal in Article 5 of the ILO Convention or the RESC. It is referred to in paragraph 5(a) of the ILO Recommendation but with the caveat that it is 'subject to national law and practice regarding retirement'.

The next valid reason in Article 4 of the ILO Convention and Article 24 RESC is 'conduct'. Two categories of misconduct have been identified by the CEACR: ${ }^{136}$

(a) inadequate performance of contractual duties, such as neglect, violation of work rules, disobedience of legitimate orders etc, or

(b) improper behaviour, such as disorderly conduct, violence, assault, using insulting language, disrupting the peace of the workplace etc.

Misconduct outside of the workplace would not normally be a valid reason for dismissal. The ESRC has found that a prison sentence delivered in court for employmentrelated offences can be a valid reason for dismissal but not if the offence is not employment-related unless the length of the custodial sentence prevents the person carrying out their work. ${ }^{137}$

The final valid reason for termination is one connected with the operational requirements of the undertaking, establishment or service. In these cases the dismissal must be for economic reasons not connected with capacity or conduct. Classically this will be a redundancy involving either a reduction of the workforce or closure of the undertaking. ${ }^{138}$ The CESR has not specified whether economic reasons must be limited to situations where employers are in difficulty or whether they can include other business strategies. $^{139}$

Participation in trade union activities is listed among the reasons not constituting valid reasons for termination in Article 5 of the ILO Convention and the appendix to Article 24 RESC. Based on the case law of the European Court of Human Rights this must also include participation in strikes as it is ultimately derived from freedom of association as guaranteed by Article 11 ECHR. ${ }^{140}$ More precise provisions are found in Articles 5 and 6(4) ESC. Potentially, Article 30 can also be invoked. Under Article 7 of Directive 2002/14 on information and consultation of workers at national level, ${ }^{141}$ Member States must ensure that employees' representatives, when carrying out their functions, 'enjoy adequate protection and guarantees to enable them to perform properly the duties which have been assigned to them'. In Holst ${ }^{142}$ the Court of Justice ruled that dismissal on grounds of status or carrying out the functions of an employees' representative 'could be regarded as constituting unfair dismissal under [national] law'.

\footnotetext{
${ }^{136}$ CEACR Note 2009, above n124, p 2.

${ }^{137}$ CESR Conclusions 2005, Estonia, pp 205-10.

${ }^{138}$ CEACR Note 2009, above n124, p. 2.

${ }^{139}$ CESR Conclusions 2003, France, p 191.

${ }^{140}$ ECtHR, Enerji Yapi-Yol Sen v Turkey [2009] no. 68959/01.

${ }^{141}$ Council Directive 2002/14/EC of the European Parliament and of the Council of 11 March 2002 establishing a general framework for informing and consulting employees in the European Community, OJ L80, 23.03.2002, p 29.

${ }^{142}$ Case C-405/08 Ingeniфrforeningen i Danmark, acting on behalf of Bertram Holst $\mathrm{v}$ Dansk Arbejdsgiverforening [2010] ECR I-985, para 63.
} 
Similar arguments can be mounted for contending that dismissal of strikers facing collective redundancy, without carrying out the information and consultation requirements in the Collective Redundancies Directive, 98/59, would amount to dismissals for 'reasons not related to the individual workers concerned' contrary to the Directive. $^{143}$

In cases involving 'temporary absence from work because of illness or injury', which is not a valid reason for termination, ${ }^{144}$ a time limit can be placed on protection against dismissal according to the CESR. ${ }^{145}$ Absence can constitute a valid reason for dismissal if it severely disrupts the smooth running of the undertaking and requires a permanent replacement for the absent worker. Additional protection must be offered, where necessary, for victims of employment injuries or occupational diseases. ${ }^{146}$

The right of a worker who considers that his employment has been terminated without a valid reason to appeal to an impartial body is contained in the final paragraph of Article 24 RESC and Articles 8-9 of the ILO Convention. Article 8(3) of the Convention allows for a time-limit on claims. The burden of proof is not placed expressly on the employer but the worker does not have to bear it alone. ${ }^{147}$ The Recommendation is stronger on the possibility of conciliation procedures before or during an appeal. ${ }^{148}$ If employment is terminated for economic reasons the appeal body must be empowered to investigate the economic facts underlying the measures according to the CESR. ${ }^{149}$

Additional provisions in the ILO Convention concern the entitlement of the worker to a severance allowance and other income protection ${ }^{150}$ and for consultation of workers' representatives in the case of collective dismissals. ${ }^{151}$ Whilst the latter is similar in content to Directive 98/59, the interpretation of the CEACR, discussed in DI above, indicates the need for protection against dismissal in cases where there are breaches of the information and consultation procedures.

\section{Limitations and Derogations}

'Every worker' is within the personal scope of application of Article 30 but the right to protection against unjustified dismissal operates 'in accordance with Union law and national laws and practices'. This limits the scope of application not only in EU law, as discussed in part A, but also, the international instruments allow for a significant degree of vertical subsidiarity and flexibility. As noted in CIII and IV above, the ILO Convention and Recommendation, and also the appendix to the RESC, permit States to exclude some of the most precarious workers from protection.

Let us consider the scope of these limitations and derogations by reference to the ILO Convention. The first excluded group are 'workers engaged under a contract of

\footnotetext{
${ }^{143}$ See B Bercusson, European Labour Law, Second Ed (Cambridge, Cambridge University Press) 315-16.

${ }_{144}$ Art 6(1) of ILO Convention No 158 and the appendix to the RESC, point 3(f).

145 Conclusions 2005, Norway, pp 572-75.

${ }^{146}$ Conclusions 2003, France, p 191.

147 CEACR GS 1995, para 199.

${ }^{148}$ ILO Recommendation No 166, para 14.

${ }^{149}$ Conclusions 2003, Bulgaria, p 78.

${ }^{150}$ ILO Convention No 158, Art 12.

${ }^{151}$ Ibid, Art 13-14.
} 
employment for a specified period of time or a specified task'. ${ }^{152}$ There is a caveat that 'adequate safeguards' must be provided 'against recourse to contracts of employment for a specified period of time the aim of which is to avoid the protection resulting from this Convention'. ${ }^{153}$ Bearing in mind the tripartite nature of the ILO, it is hardly surprising that the social partners negotiated a clause in the Framework Agreement annexed to the EU Fixed-term Work Directive, 1999/70, which requires Member States to introduce measures to 'prevent abuse' of successive fixed-term employment contracts or relationships. ${ }^{154}$ This may have some limiting effect on the exclusion and it should be noted that fixed-term 'employees' are protected against dismissal in some legal orders, such as the UK. ${ }^{155}$ Also, the Cour de Cassation in France has relied directly on the safeguarding clause in the ILO Convention when striking down a national law on successive fixed-term contracts that had permitted termination without justification. ${ }^{156}$

The second excluded group are 'workers serving a period of probation or a qualifying period of employment, determined in advance and of reasonable duration'. ${ }^{157}$ This leaves open the question of how long is a 'reasonable duration' for a qualifying period. There is important guidance on this point from the CESR and the ILO. The CESR has found that the exclusion of employees from protection against dismissal for six months 'is not considered reasonable if it is applied indiscriminately, regardless of the employee's qualifications'. ${ }^{158}$ An interesting test case has been decided by the ILO. In response to a French law introducing a two year qualifying period relating to individual and collective dismissals for undertakings with no more than 20 employees, the Confederation Générale du Travail alleged non-observance by France of the Convention and, in response, the ILO established a Tripartite Committee to investigate. In 2008 the Tripartite Committee concluded that a period as long as two years was not reasonable for excluding all of the employees concerned. ${ }^{159}$ The French Cour de Cassation subsequently found that the legislation did not fall into one of the categories that can be excluded from the Convention. 160

This guidance is of interest in the light of recent developments in the UK. In 2012 the UK introduced delegated legislation to vary the qualifying period for unfair dismissal from one year to two years for all claims. ${ }^{161}$ The Trades Union Congress estimated that 2.7 million employees would be excluded from bringing claims as a result of this

\footnotetext{
152 Ibid, Art 2(2)(a).

153 Ibid, Art 2(3).

${ }^{154}$ Council Directive 1999/70/EC of 28 June 1999, OJ L 175, 10.7.1999, p 43. The relevant provisions are contained in clause 5 of the annexed agreement between the social partners. Clause 2 leaves the definition of 'fixed-term workers who have an employment contract or employment relationship' to national law.

155 Employment Rights Act, 1996, s95(1)(b).

${ }^{156}$ Samzun v de Wee, 1 July 2008, Appeal No F 07-44.124: http://compendium.itcilo.org/en/text-fullsearch/\#

${ }^{157}$ ILO Convention No 158, Art 2(2)(b).

${ }^{158}$ ECSR Digest, 2008, above n71, p 152.

${ }^{159}$ ILO Governing Body document GB.300/20/6.

${ }^{160}$ Case No 1210 .

${ }^{161}$ Unfair Dismissal and Statement of Reasons for Dismissal (Variation of Qualifying Period) Order 2012, effective from 6 April 2012.
} 
change. ${ }^{162}$ The UK, by deciding to reduce the scope of protection, chose to disregard the views of the ILO Tripartite Committee and the CESR. Indeed, the UK Government may consider that it can act with impunity using national law relying on the limitations in Article 30 and the language in Article 2 of Protocol No 30 concerning the UK and Poland. Moreover, the order of the Court of Justice in $\mathrm{Nagy}^{163}$ indicates that an employee in the UK affected by this change would have no recourse under EU law regardless of the Protocol. Nevertheless, the UK may be in serious breach of international law by acting retrogressively to weaken the protection of workers from unjust dismissal. As noted in CII above, the duty of State parties, including the UK, under Article 6 of the UN ICESCR on the right to work includes safeguarding the protection of workers against unfair dismissal. In its General Comment No 18 on Article 6, the CESCR stressed the progressive realisation of the right and concluded that, if any 'deliberately retrogressive steps are taken', State parties have the burden of proving that they have considered all alternatives in the context of the ICESCR as a whole and the use of maximum available resources.

States can also exclude a third group of 'workers engaged on a casual basis for a short period'. ${ }^{164}$ Guidance from the ECSR is somewhat ambiguous on this point. According to the ECSR, all workers who have signed an employment contract are entitled to protection in the event of termination of employment. ${ }^{165}$ The language suggests that States have a margin of discretion to exclude many workers who do not have standard contracts of employment or formal 'employee' status.

There is also scope for States to exclude workers whose terms of employment are governed by 'special arrangements' which provide protection at least equivalent to the protection afforded under the ILO Convention subject to consultation with the social partners. ${ }^{166}$ Finally, States may exclude workers where 'special problems of a substantial nature' arise in the light of the particular conditions of employment of the workers concerned 'or the size and the nature of the undertaking' that employs them, also subject to consultation with the social partners. ${ }^{167}$ As the ILO Tripartite Committee decision concerning France demonstrates, the flexibility permitted by the latter does not allow for a general exclusion of small businesses from the Convention. ${ }^{168}$

V Remedies

Art 47 of the Charter reinforces the principle of effective remedies that is well known in EU labour law. The asymmetric power relationship between the employer and the worker requires strong and effective remedies for violation of fundamental social rights. In the context of EU equality law the national court must impose a penalty such as to 'guarantee

\footnotetext{
${ }^{162}$ Based on the UK Labour Force Survey of 2011. See TUC press release, 2 April 2012: http://www.tuc.org.uk/equality-issues/around-27-million-workers-increased-risk-losing-their-jobs-whenunfair-dismissal-law

${ }^{163}$ Cases C-488-491/12 and 526/12 Nagy and others, Order of the Court, 10 Oct 2013. See DI above.

${ }^{164}$ Ibid, Art 2(2)(c).

165 Conclusions 2003, Statement of Interpretation on Article 24: http://www.coe.int/t/dghl/monitoring/socialcharter/conclusions/conclusionsyear_EN.asp

${ }^{166}$ ILO Convention No 158, Art 2(4).

${ }^{167}$ Ibid, Art 2(5).

${ }^{168}$ ILO Governing Body document GB.300/20/6.
} 
real and effective judicial protection ... it must also have a real deterrent effect on the employer'. ${ }^{169}$ The principle of 'effective, proportionate and dissuasive' penalties is becoming standard in EU labour law directives. ${ }^{170}$ The worker who is deprived of their livelihood following a dismissal that they consider to be unjust is in the greatest need of procedural fairness and an effective remedy.

Under Article 10 of the ILO Convention the remedies are reinstatement or the payment of adequate compensation or such other relief as maybe appropriate. According to the CESR, in its case law on the equivalent provision in Article 24(b) RESC, the worker who has been unjustly dismissed should be reimbursed for financial losses incurred between the date of dismissal and the decision of the appeal body. ${ }^{171}$ In addition, compensation should be of a 'high enough level to dissuade the employer and make good the damage suffered by the employee'. ${ }^{172}$

Reinstatement reverses the dismissal by correcting the injustice. The worker returns to the same job, or a comparable job, with arrears of pay, as if there had been no dismissal. $^{173}$ The option of reinstatement under the ILO Convention is heavily circumscribed. Only bodies that are empowered under national law to order or propose reinstatement are required to consider this option. Even if these bodies are empowered to order reinstatement they may find that it is not 'practicable'. These matters are left to 'national law and practice'. Once again the formulation of 'national law and practice' renders the reinstatement remedy nugatory except in those legal orders, such as Italy, that have hitherto taken it seriously because they recognise the worker's interest in job security. ${ }^{174}$ In the UK the Employment Tribunal is required to always consider the remedy of reinstatement first but will only order it if the employee wishes to be reinstated and 'it is practicable for the employer to comply with the order'. ${ }^{175}$ In 2011-12 reinstatement or re-engagement was awarded in just five out of 5,100 cases where the case was upheld. ${ }^{176}$

\section{E. Evaluation}

Article 30 on the right to protection against unjustified dismissal has an enigmatic quality. The 'fundamental principle of justification' is firmly established at the UN, the ILO and the Council of Europe. It is the most salient of fundamental social rights because, perhaps more directly than any comparable right in the Charter, it asserts the principle that labour is not a commodity or article of commerce. ${ }^{177}$ It has been invoked purposively by the European Court of Human Rights when interpreting the ECHR and yet there is a void at EU level. Neither the Commission, which has the imperative to act

${ }^{169}$ Case 14/83 Von Colson [1984] ECR 1891, para 23.

${ }^{170}$ For example, see Art 10(2) of Directive 2008/94/EC of the European Parliament and of the Council of 19 November 2008 on temporary agency work, OJ L 327, 5.12.2008, p 9.

${ }^{171}$ Conclusions 2003, Bulgaria, p 78.

172 ECSR Digest, above n71, p 154.

173 See Collins, above n9, p 216.

174 Ibid, p 217 ,

${ }^{175}$ Employment Rights Act 1996, s116(1).

${ }^{176}$ See: https://www.gov.uk/government/publications/employment-tribunal-and-employment-appealtribunal-statistics-gb

177 See P O'Higgins, 'Labour is not a Commodity' - an Irish Contribution to International Labour Law' (1997) 26 ILJ 225. 
on a clear legal basis, nor the Court of Justice, which has a duty to interpret and apply Article 30 in the context of a wide range of legislation where it is, at least, incidentally, relevant, has been prepared to give it meaning in EU law. By contrast, the freedom to conduct a business is now strongly rooted in the jurisprudence of the Court of Justice and being applied to limit the scope of EU labour law directives.

Perhaps the best explanation for the enigma of Article 30 is a dual identity crisis. The first identity crisis is internal to Article 30 and the norms from which it is sourced. In seeking to balance such a multitude of interests - job security, the managerial prerogative, and the needs of society - it lacks a clear focus. Its limitations and derogations exclude millions of casual and short-term workers who are the most vulnerable to the risk of unjust dismissal. Member States are unravelling decades of employment protection without giving Article 30 a second glance.

The second identity crisis is within the EU. Is the EU serious about balancing the economic and social dimensions of integration? What does the mishmash of flexibility and security - so-called 'flexicurity' - really mean for those inside and outside the labour market? There are some who regard job security as an anomaly and Article 30 as anachronistic and outmoded when $50 \%$ or more of young people in southern Europe are out of work. An alternative view, however, is that the economic crisis shines a light on the need for stronger international labour standards respected and promoted in EU law. Research has shown that dismantling the legal protection of workers facing termination of employment has been inefficient in terms of economic recovery and has undermined productivity. ${ }^{178}$ The ILO has identified the termination of employment instruments as among the most relevant of its norms at a time of global economic crisis when stability is needed to protect livelihoods, reconcile work and private life and maintain social peace. $^{179}$

It is time for Article 30 to cease to be an enigma. What this chapter has shown is that there is plenty of guidance in international law to give it greater clarity and meaning. Even in the absence of a core unjust dismissal measure at EU level, there are sufficient interconnections between Article 30 and existing norms across the breadth of EU social law to advance fairness in the employment relationship.

\footnotetext{
${ }^{178}$ S Cazes and A Nesperova, Flexicurity, a relevant approach in Central and Eastern Europe (Geneva, International Labour Office, 2007).

${ }^{179}$ ILO Global Jobs Pact, 2009, para 14.
} 